\title{
Probable ATP-Dependent RNA Helicase DDX31
}

National Cancer Institute

\section{Source}

National Cancer Institute. Probable AT P-Dependent RNA Helicase DDX31. NCI

Thesaurus. Code C107453.

Probable ATP-dependent RNA helicase DDX31 (851 aa, $~ 94 \mathrm{kDa}$ ) is encoded by the human DDX31 gene. This protein plays a role in the regulation of RNA secondary structure. 